\title{
Life Cycle Inventory Analysis of Basic Oils for Manufacturing of Automotive Lubricants
}

\author{
Geraldo J O Figueiredo \\ Programa de Engenharia Ambiental. Escola Politécnica da \\ Universidade Federal do Rio de Janeiro \\ Athos da Silveira Ramos \\ 149 - Ilha do Fundão - Centro de Tecnologia - Bloco D \\ 207 - Cidade Universitária - 21.941-909 - Rio de Janeiro - RJ \\ - Brasil
}

Eduardo L Qualharini

Programa de Engenharia Ambiental. Escola Politécnica da Universidade Federal do Rio de Janeiro

Athos da Silveira Ramos

149 - Ilha do Fundão - Centro de Tecnologia - Bloco D 207 - Cidade Universitária - 21.941-909 - Rio de Janeiro - RJ - Brasil

\begin{abstract}
Life cycle inventory analysis of basic oils shows the impacts generated in the process of producing related products to virgin lubricant oils (VLO). That comes out in the first petroleum refining and the impacts of the used or contaminated lubricant oils (ULOC). In this paper the impacts will be shown in a numerical way, by direct observation or chemical similarity using such databases as the Echo 99 indicator. Results determine actions to be taken in future decision making process
\end{abstract}

Keywords-Life cycle inventory assessment; Basic oils; Lubricants, Eco indicator

\section{INTRODUCTION}

The present work aims at the inventory analysis of basic lubricant oils that are used in the producing of automotive lubricants in the State of Rio de Janeiro, Brazil. The lubricant oil is a crucial element for the good operation of the automobile engines because they present friction between the pieces. The automotive lubricant has the function to reduce or eliminate the friction, extending the useful life engine and becoming easier its operation. A petroleum refinery is a group of industrial installation that transforms the crude petroleum and other raw materials into petroliferous goods finished. The refining capacity refers to the maximum amount of crude oil conceived to flow into the distillation unit of a refinery, also known as the crude unit.

When analyzing impacts caused by basic oils and lubricants one may have a macro vision, when we can observe the transportation modals that vary among tank trucks, tank wagons and tank ships, the last one being which dislocates a bigger volume and has the biggest potential for damage, we can realize that an accident may generate losses and environmental financial of a big cost in a short time. One also can have a micro vision related to its impacts when we observer the inadequate discard day by day. Any commercial

\author{
Assed N Haddad * \\ Programa de Engenharia Ambiental. Escola Politécnica da \\ Universidade Federal do Rio de Janeiro \\ Athos da Silveira Ramos \\ 149 - Ilha do Fundão - Centro de Tecnologia - Bloco D \\ 207 - Cidade Universitária - 21.941-909 - Rio de Janeiro - RJ \\ - Brasil
}

\section{Elaine G Vazquez}

Programa de Engenharia Ambiental. Escola Politécnica da Universidade Federal do Rio de Janeiro Athos da Silveira Ramos

149 - Ilha do Fundão - Centro de Tecnologia - Bloco D 207 - Cidade Universitária - 21.941-909 - Rio de Janeiro - RJ - Brasil

establishment that has the proposal to change the engine oil, does not worry about the destination of the contaminated and used oil (CUOL), what many times it's going to be discard in a criminal way in water bodies, in the soil or it can be used in an incorrect way as proofing, insect repellents (termite), chainsaw lubrication and other uses a little noble. The CUOL can be refined several times, increasing the offer of basics in the lubricant market and this way reducing the need of virgin basic oils. The lubricant oil used is among the major difficulty pollutants of manipulating anthropogenic, due to its toxicity [1].

\section{Production of Basic Oil from the Petroleum REFINING}

The lubricant section must always be considered to environmental issues, becoming necessary to know, quantify and qualify the resources used, the rests, as well as the emissions generated in the final destination of UOL [2].

Petroleum in its primitive state (the way it is retired from the oil well) is stored in tanks, and these ones will occur pumps for a furnace where the petroleum will be heated up in high temperatures and this way, it is going to occur the first atmospheric distillation where it happens the separation as the weight of each product, from the lightest according to the gas and the gasoline to the heaviest, according to the lubricant oils, wax and asphalt.

Atmospheric distillation aims at separating the materials derived from the petroleum, as its boiling points respective. The petroleum is heated up to a temperature about $370 \mathrm{C}$ and lead to a tower under gas and liquid form, where its materials derived are separated. The atmospheric distillation tower is composed by a series of trays where exist the bubbling valves. The liquid part, or condensate, goes down and it is retired by the deep. The gaseous tends to go up. It happens because the 
temperature inside the tower is higher in the deep, decreasing as it approaches to the top. Each tray has a different temperature, and so they condensate the hydrocarbons whose dew points were inferior to the tray temperature. Gases, going up in the tower, helped by the steam that is also injected, pass through the glasses and bubble in the liquid condensate there. If the its boiling point is inferior to the liquid temperature, they condensate each other and stay on the tray.

However, if its boiling point is superior, they stay under gaseous form, they continue going up, and pass through the following trays, until they find the necessary temperature to condensate. The trays have a (reflow) return for the immediately inferior. It is necessary for the hydrocarbons, which should stay in the inferior tray and consequently were dragged up, return to its place. The hydrocarbons that went down, but they should stay in the superior tray, when reaching the tray below, whose temperature is bigger than the boiling point, they become gases again and go up from the original tray. The tray are kept to a constant temperature, and some of them are, so, retired the desired fractions. The most elevated boiling point fractions are retired by the tower deep, in a form of fuel oil or reduced raw.

\section{Oil Basic Production from the Re-Refining of ULOC}

The re-refining process in Brazil counts on technology that serves the patterns demanded by the petroleum national agency ordinances that are going through by a review process.

Nowadays there are three different technologies for acquisition of basics from the ULOC:

A. Clay acid System with " term cracking .. In this technology predominates the acquisition of high viscosity oil.

B. Distillation in a flash System or particular evaporation. In this technology predominates the acquisition of basic oils, neutral oil and light oil.

C. System by extraction to a selective propane solvent. In this technology predominates the acquisition of basic neutral oil.

The recycling plants usually work with more than a technology aiming for a production of light and high viscosity oil. In a visit that operates in the State of Rio de Janeiro was possible to observe the whole process. The plant could show that it has been contributing to stop that the evictions that the used lubricant oils be thrown in the sewage systems from overflowing and the plant has provided boundaries economy for preserving the natural resource non renewable and contributing in order to part of this material cannot be imported.

\section{A Life Cycle Inventory of Oils Basic Oils}

Data collection is considered the life inventory phase, according to [1]. Everything that comes in must have equal when something goes out from the system in study related to mass and energy since the extraction from raw material to the final product discard. The life cycle analysis is a difficult phase considering mainly the difficult in the data collection. The life cycle assessment shows, in its structure, four steps. One of these steps is the analyses of life cycle inventory ( LCI ) where the effects or environmental cargos generated during the life cycle of a product or service must be identified, aiming at considering and quantify entrances and exits for the investigated system environment .

In the normative context and the application, the LCI bases on the definition of objective and area and of the system limits, flow diagrams with process units where data collection must be established for each one of these allocation process and other calculations.

\section{B Eco Indicator 99}

The Echo 99 indicator is a manual for designers and production managers that want to apply the values of eco indicator for the analysis of production systems environmental aspects. The eco indicator 99 considers three types of damage: Human health, in this category is included the number and the disease duration considering the lost years by a premature death due to the environmental causes. In this category are also included the climatic changes, the dimming layer ozone, the carcinogenic effects, breath problems and ionizing radiation. The environmental quality is other type of damage, in this category are included the effects about biodiversity. Among the included effects are the eco toxicity, acidification, eutrophication and the soil use. The resources, take part from the types of damage also considered in the gauge echo 99, in this category is included the extra need energy in the future for the mineral extraction, the crude material dimming as sand and others.

TABLEI. IMPACT CATEGORIES FOR FOSSIL FUELS

\begin{tabular}{|l|l|}
\hline \multicolumn{1}{|c|}{ Impact Category } & \multicolumn{1}{c|}{ Damage } \\
\hline $\begin{array}{l}\text { carcinogenic } \\
\text { respirable inorganic } \\
\text { climate change } \\
\text { ozone layer } \\
\text { organic respirable }\end{array}$ & human health \\
\hline $\begin{array}{l}\text { land use } \\
\text { ecotoxicity } \\
\text { acidification and eutrophication }\end{array}$ & quality of ecosystems \\
\hline $\begin{array}{l}\text { fossil fuels } \\
\text { Minerals }\end{array}$ & natural resource depletion \\
\hline
\end{tabular}

\section{ANALysis OF THE LIFE CyCLE INVENTORY OF BASIC} OILS

The automotive lubricant oil production has the beginning in the production of petroleum in the oil well. For this work, it will be done an inventory analysis having as system boundary the crude oil, that enters in the distillation tower and the ended oil that is the basic for the producing automotive lubricants. The process has the beginning with two different forms of distillation, the Atmospheric distillation , the crude petroleum after heating up, enters in the distillation tower where it occurs the first separation. And the distillation vacuous, where happens the second separation stage. This crude basic oil passes through deflavorization, de axing and hydro finishing for the market.

For the used lubricant oil and / or contaminated (ULOC) the boundaries are the oil originating from the collection by the conversion into basic for the production of automotive 
lubricants. The process has the beginning in the collection of ULOC that is taken to a recycling where it will be re refined. The re-refining process of ULOC begins with a pre treatment. The pre-treatment of UO consists, generically, in the physicchemistry analysis of UO (\% water, sediments, CP), in its filtration, decantation, distillation and centrifugation. In some cases the crionization (freezing bodies process above 196 Celsius) and saponification from the final product [3].

After the cited phases the basic is ready to receive additive and be available for the market, having the same characteristics of produced lubricant oil originating from the first re-refining. A controversial element, in the production process of VLO is the furfural. The main consumption cause of furfural is its degradation. Additional losses are possible through the displacement or condensate ejection [4]. VLO.

Tables 2 and 3 present the Inventory to obtain from basic

TABLEII. INVENTORY TO BASICS FROM VLO

\begin{tabular}{|c|c|c|c|c|}
\hline $\begin{array}{c}\text { RAW } \\
\text { MATERIAL }\end{array}$ & UNIT & QUANTITY & INDICATOR & TOTAL \\
\hline crude oil & $\mathrm{Kg}$ & 1000 & 180 & 180000 \\
\hline natural gas & $\mathrm{M}^{3}$ & 100 & 5,3 & 530 \\
\hline hydrogen & Kg & 0,61 & 830 & 506,3 \\
\hline electrical energy & $\begin{array}{l}\text { MW- } \\
\text { h }\end{array}$ & 11,6 & 22 & 255,2 \\
\hline TOTAL & & & & 181291,5 \\
\hline \multicolumn{5}{|l|}{ PRODUCT } \\
\hline Oil Down & $\mathrm{Kg}$ & 520 & 180 & 93600 \\
\hline Aromatic Extratic & $\mathrm{Kg}$ & 350 & 180 & 63000 \\
\hline Candle Wax & $\mathrm{Kg}$ & 45 & 180 & 8100 \\
\hline gasoline & $\mathrm{Kg}$ & 85 & 180 & 15300 \\
\hline TOTAL & & & & 180000 \\
\hline \multicolumn{5}{|l|}{ wastewater } \\
\hline Furfural & $\mathrm{Kg}$ & 0,54 & 99 & 53,46 \\
\hline MIBK & $\mathrm{Kg}$ & 1,32 & 99 & 130,68 \\
\hline Water (da AGR) & $\mathrm{M}^{3}$ & 27,3 & 0,026 & 0,7098 \\
\hline TOTAL & & & & 184,8498 \\
\hline \multicolumn{5}{|l|}{ Emissions } \\
\hline $\mathrm{CO} 2$ & $\mathrm{Kg}$ & 213 & $* * *$ & \\
\hline $\mathrm{H} 2 \mathrm{O}$ & $\mathrm{Kg}$ & 71 & 0,026 & 1,846 \\
\hline TOTAL & & & & 361478,20 \\
\hline
\end{tabular}

TABLEIII. INVENTORY TO BASICS FROM ULOC

\begin{tabular}{|l|l|l|l|l|}
\hline $\begin{array}{l}\text { RAW } \\
\text { MATERIAL }\end{array}$ & UNIT & QUANTITY & INDICATOR & TOTAL \\
\hline ULOC & $\mathrm{Kg}$ & 1000 & 180 & 180000 \\
\hline Sulphuric acid 98\% & $\mathrm{Kg}$ & 97,4 & 22 & 2142,8 \\
\hline Sodium hydroxide & $\mathrm{Kg}$ & 14 & 38 & 532 \\
\hline Water & $\mathrm{Ltr}$ & 1360 & 0,026 & 35,36 \\
\hline electrical energy & $\mathrm{MW}-\mathrm{h}$ & 129,6 & 22 & 2851,2 \\
\hline natural gas & $\mathrm{M}^{3}$ & 172,50 & 5,3 & 914,25 \\
\hline fuller's earth & $\mathrm{Kg}$ & 68 & 0,82 & 55,76 \\
\hline TOTAL & & & & 186531,37 \\
\hline EXIT & & & & \\
\hline WASTEWATER & & & & 811,8 \\
\hline $\begin{array}{l}\text { Clays and activated } \\
\text { earths }\end{array}$ & $\mathrm{Kg}$ & 990 & 0,82 & \\
\hline $\begin{array}{l}\text { atmospheric } \\
\text { emissions }\end{array}$ & & & & 3,072 \\
\hline SOx & $\mathrm{Kg}$ & 2,756 & 12 & $\mathbf{1 8 7 3 8 1 , 4 4}$ \\
\hline NOx & $\mathrm{Kg}$ & 0,433 & 12 & \\
\hline TOTAL & & & & \\
\hline
\end{tabular}

\section{CONCLUSION}

The present study shows in an overall way using just an indicator for the environmental aspect analysis production, the re refining importance of used lubricant oils and / or contaminated (ULOC), faced with the current scenario in the industrial recycling The recycling used lubricant oils can be observed such an example of the industrial metabolism, because the final residual after utilization by the consumer enters, after treating, again in the production cycle as raw material. We can watch that in the Table 2, for the basic obtainment from the virgin lubricant oils (VLO), the numerical total reflects a bigger environmental cost provoked by the basic oil from the first petroleum refining related to the one in the Table 3, for the basic produce from the used oil (ULOC) in which reflects a smaller environmental cost. The generation of ULOC tends to increase as the vehicle fleets increase, mainly in the big cities. The wrong destination causes environmental impacts in effluent liquid receiver bodies and mainly in the atmosphere when it comes from the ULOC burning in the furnaces and blast furnace due to its thermal potential. The eco indicator 99 does not consider carbon emissions but, as the graph below shows, the ULOC incineration in furnaces and also in great potential ovens for the global warming.

Considering that the atmospheric pollution generates damage to human health and the petroleum exploration, besides the damage for the soil and surroundings in the research phase and perforation, it generates the consumption and the resource depletion. The ULOC recycling for the automotive lubricant basic production is an economical and environmental advantage.

\section{REFERENCES}

[1] Vorapot K, et al. () Worapon Kiatkittipong, Bunyarit Panyapinyopol, Porntip Wongsuchoto, Prasert Pavasant. Used lubricating oil management options based on life cycle thinking, Resources, Conservation and Recycling, Volume 53, Issue 5, March 2009, Pages $\begin{array}{ll}\text { 294-299, } & \text { 0921-3449, }\end{array}$ http://dx.doi.org/10.1016/j.resconrec.2009.01.002.

[2] U.S.Energy Information Administration, Grude Oil Distillation Unit and Products 07/2012. Www.Eia.Gov/Todayinenergy/Detail.Cfm?Id=6970 
[3] ISO 14041 Environmental management -- Life cycle assessment -- Goal and scope definition and inventory analysis. 2006.

[4] Georgios G. et al. Analysis of the recycling potential of used automotive oil filters using the Life Cycle Assessment approach. 2011. 